\title{
Distribution survey of Cyanobacteria in three Greek caves of Peloponnese
}

\author{
Vasiliki Lamprinou $^{1}$, Daniel B. Danielidis ${ }^{1}$, Athena Economou-Amilli1*, and \\ Adriani Pantazidou ${ }^{1}$
}

\begin{abstract}
:
Lamprinou V., Danielidis D.B., Economou-Amilli A. and Pantazidou A. 2012. Distribution survey of Cyanobacteria in three Greek caves of Peloponnese. International Journal of Speleology, 41(2), 267-272. Tampa, FL (USA). ISSN $0392-6672$. http://dx.doi.org/10.5038/1827-806X.41.2.12

Caves and hypogean environments host various phototrophic microorganisms, with Cyanobacteria constituting the major group. The spatial and temporal distribution of Cyanobacteria (156 taxa in total) from three Greek caves, located in the limestone arc of Peloponnese and differing in morphology, was studied. The community patterns in different ecological niches were analyzed in relation to environmental parameters (Photosynthetically Active Radiation, Temperature, and Relative Humidity). Cyanobacterial communities were found to thrive in patchy biofilms and showed known protective strategies against desiccation and irradiation. The nMDS analysis of the cumulative seasonal samples per sampling site showed no general pattern of distribution, with a clear differentiation of cyanobacterial communities among the three caves. Only in the typical cave 'Kastria', cyanobacterial taxa showed growth habits in accordance with the gradient of light from entrance inwards.
\end{abstract}

Keywords: cyanobacterial communities; hypogean habitat; environmental parameters; ecological niches; Greek caves Received 27 March 2012; Revised 7 May 2012; Accepted 14 May 2012

\section{INTRODUCTION}

Caves are classified according to the composition of the lithic substrate, the proximity to the groundwater table, the spelaeogenic history, and the overall passage morphology. Limestone caves are highly specific environments scattered all over the world (Hoffmann, 1989; Hernández-Mariné et al., 2001; Roldán et al., 2004), and karst caves are considered a specific case of extreme environment (Culver et al., 2004; Mulek \& Kosi, 2008). The term 'extreme' is usually defined in a mathematical sense as belonging to the outer parts of a Gaussian distribution, i.e., as 'extraordinary'. However, among biologists it should be clear that this definition has to be handled carefully. As soon as there are organisms able to settle down, those habitats are no longer extreme in a biological sense (Seckbach et al., 2007).

Most caves represent stable environments characterized by uniform temperatures throughout the year, high humidity and low natural light. A typical cave is described as having three major habitat zones based on light penetration and intensity: the entrance-, transition-, and dim light zone. Even caves with dim natural light have been found to host phototrophic mi-

${ }^{1}$ University of Athens, Faculty of Biology, Department of Ecology and Systematics, Panepistimiopolis, Athens 15 784, Greece.

* Corresponding author (aamilli@biol.uoa.gr) croorganisms where the low Photosynthetically Active Radiation (PAR) is the pressure and maybe one of the divergence forces for selection (Roldán \& HernándezMariné, 2009). Moreover, cave characteristics such as dimensions, morphology, location, orientation and lithic substrate can play important role to the biocommunity structure.

The taxa recorded in caves have been categorized (e.g. Hoffmann, 2002) into three groups: a) 'troglobitic' species, obligatory cavernicoles that cannot survive outside the cave, b) 'troglophilic' species, growing and reproducing in caves, and c) 'trogloxenic' species, accidentally reaching the cave environment. Concerning cyanobacteria, some species such as Loriella osteophila Borzi, Scytonema julianum (Kützing) Meneghini Richter can be considered as troglophiles (Hoffmann, 2002). Very few cyanobacteria are considered as obligatory cavernicolous such as Geitleria calcarea Friedmann, G. floridana Friedmann, Herpyzonema pulverulentum Hernández-Mariné \& Canals, and Symphyonema cavernicolum Asencio, Aboal \& Hoffmann. Hypogean environments including caves have been studied worldwide: Brasil (Sant'Anna et al., 1991), Israel (Friedmann, 1964; Vinogradova et al., 1998), Hungary (Claus, 1964; Hajdu, 1966), France (Bourelly \& Dupuy, 1973; Leclerc et al., 1983), Germany (Dobat, 1977), Italy (Borzi, 1917; Skuja, 1970; Abdelahad, 1989), Romania (Şerbānescu \& Decu, 1962), Slovenia (Mulek \& Kosi, 2008), Spain 
(Ariño et al., 1997; Ascencio \& Aboal, 1996, 2000a,b,; Martinez \& Asencio, 2010; Hernández-Mariné et al., 2001; Roldán et al., 2004), and Greece (Anagnostidis et al., 1982; Lamprinou et al., 2009, 2011, 2012a,b,c). Despite all the aforementioned mainly floristic studies, it is only recently that cave microbiology has been established as a new field combining aspects of microbial life, geology and chemistry that influence the natural cave processes (Mulek \& Kosi, 2008).

The aim of this study is to present the spatial and temporal distribution of cyanobacteria in three Greek caves differing in location and morphology, to analyze and correlate the observed community patterns with the environmental parameters, and to study the various growth habits in relation with the ecological niches.

\section{MATERIAL AND METHODS}

The caves 'Kastria', 'Selinitsa' and 'Francthi' differ in morphology and in the proximity to the sea, and are all located in the limestone arc of Peloponnese, Greece. (Fig. 1). 'Kastria' (3757'37.54”N, 22 08'26.91'E, altitude $827 \mathrm{~m}$ a.sl). is a typical cave in terms of light gradient from the entrance inwards, located in Achaia; it actually represents an old subterranean river with an explored length of $1980 \mathrm{~m}, 500 \mathrm{~m}$ of which are touristically exploited with a separate entrance. 'Selinitsa' (36 48'10.44"N, 22 $17^{\circ}$ '51.18”'E, altitude $2 \mathrm{~m}$ a.s.1), located in Messinia, is a typical cave in terms of light gradient but influenced by the sea spray. 'Francthi' $\left(37^{\circ} 25^{\prime} 21.01^{\prime \prime} \mathrm{N}\right.$ and $23^{\circ} 07^{\prime} 51.81^{\prime \prime} \mathrm{E}$; altitude $12.5 \mathrm{~m}$ a.s.l) is an exposed, non-typical cave with partly collapsed roof, located in Argolida; according to the archaeologists, this cave represents a remarkable site on the coast of southeast Greece since its deposits cover the period from 20.000 BC down to $3.000 \mathrm{BC}$ (far prehistoric).

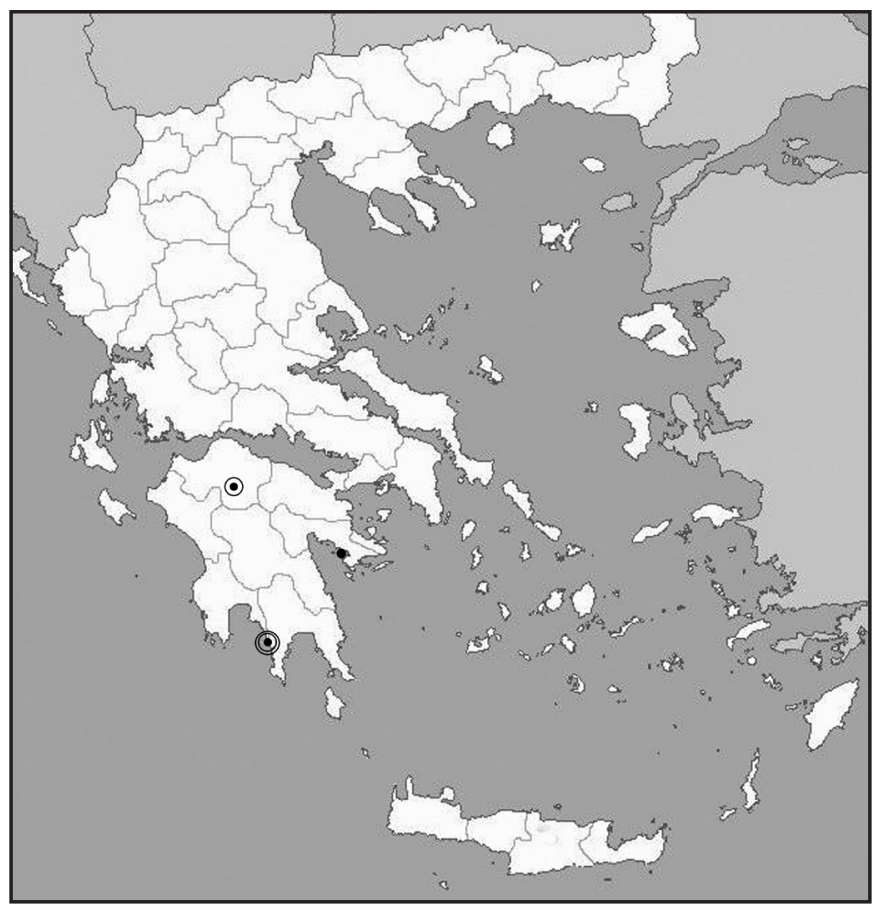

Fig. 1. Map of Greece showing the location of caves: 'Francthi' (dot), 'Kastria' (circled dot) and 'Selinitsa' (double circled dot).
Sampling was made at selected sites 1-7 in each cave starting from the physical cave entrance, hosting various growth habits of cyanobacteria. Sampling was conducted seasonally during a biannual survey (2009-2010). Air Temperature $\left(\mathrm{T}{ }^{\circ} \mathrm{C}\right)$, Relative Humidity (RH\%), and Photosynthetically Active Radiation (PAR $\mu \mathrm{mol} . \mathrm{m}^{-2} \cdot \mathrm{s}^{-1}$ ) were measured by a LI1400 data logger (LI-COR Biosciences, USA) during the survey (Table 3). Four subsamples were collected under sterile conditions from each sampling site. Two of them were incubated in situ inside transparent sterile vials, and the other two were partly fixed with formaldehyde solution at a final concentration of $2.5 \%$. Enrichment cultures were obtained in flasks and petri-dishes with BG11 and BG $11_{0}$ (Stanier et al., 1971). Cultures were maintained in incubator (SANYO, GALLENKAMP) under stable conditions (23 $\left.{ }^{\circ} \mathrm{C}, 80 \% \mathrm{RH}, 7 \mathrm{\mu mols} \cdot \mathrm{s}^{-1} \cdot \mathrm{m}^{-2} \mathrm{PAR}\right)$ and under daylight (north facing window) at room temperature for 2 years. For Light Microscopy (LM) fresh and cultured material was observed on glass slides under a highresolution light microscope (Axiolab, Zeiss, Germany). Species presence/absence data were analyzed by non-metric Multidimentional Scaling Ordination (nMDS) and Analyses of Similarities (SIMPER) based on Jaccard similarity index and the application of PRIMER software v.6. Species richness, as number of species, was used as a proxy of cyanobacterial diversity and comparisons were made through ANOVA (Statgraphics Centurion).

\section{RESULTS}

A photosynthetic microflora consisting of cyanobacteria, green algae, diatoms and bryophytes was found inhabiting sites with adequate light in all caves studied and near the cave entrances; these taxa were preserved in formaldehyde solution and are available for further taxonomic study. Cyanobacterial communities were found to prevail mainly on the cave walls, and on spelaeothems such as stalagmites and stalactites, especially in the low light zone.

After a seasonal survey in each cave and in each sampling site (1-7) the microscopic analysis (LM) revealed a total number of 156 cyanobacterial taxa (Table 1 available online at http://dx.doi. org/10.5038/1827-806X.41.2.12) belonging to the orders Chroococcales (69), Oscillatoriales (59), Nostocales (26), and true-branched Stigonematales (2). Despite the almost similar annual biodiversity in terms of number of species in the three caves ('Kastria' 76, 'Selinitsa' 71, 'Francthi' 65 taxa) only 19 taxa were common, with 12 of them belonging to Oscillatoriales.

The nMDS analysis of the cumulative seasonal samples per sampling site showed a clear distinction of the cyanobacterial community in the three caves (Fig. 2), with average dissimilarity among pairs of caves ranging between $86-89 \%$ (for the distinctive species see also the results of the analysis of similarities in Table 2).

Analysis of the average species richness per season showed differentiation among the three caves (Fig. 3): In 'Francthi' and 'Selinitsa' the average species richness per season was stable throughout the year; on the other hand, 'Kastria' showed significantly 


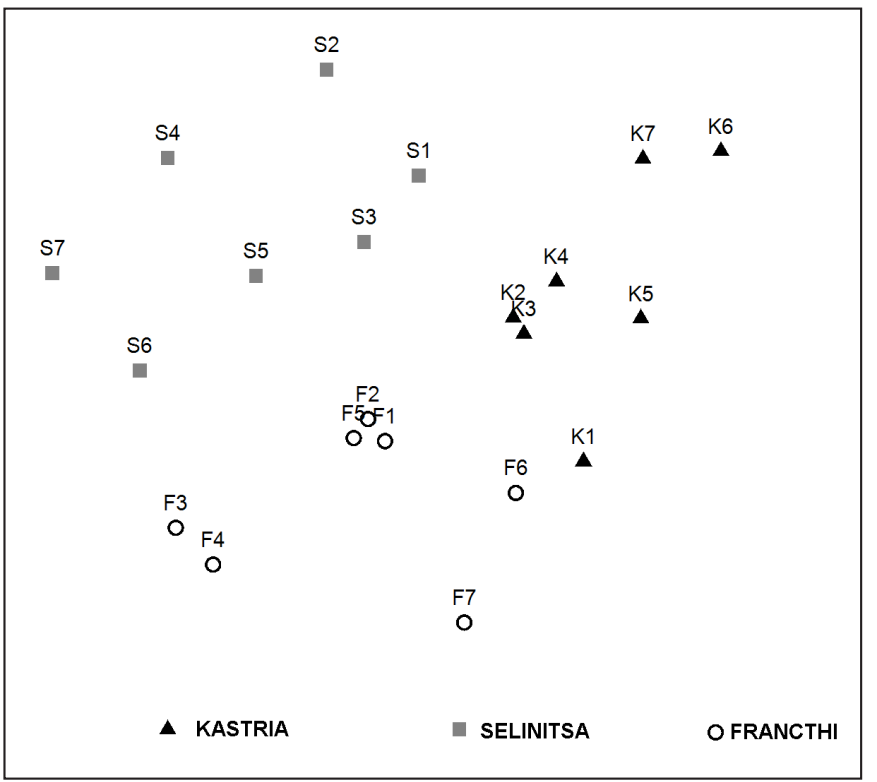

Fig. 2. nMDS analysis of the cumulative seasonal samples per sampling sites 1-7. ( $\mathrm{K}=$ 'Kastria', $\mathrm{S}=$ 'Selinitsa', $\mathrm{F}=$ ='Francthi').

higher values in autumn and winter and especially low values in spring with two sites (K1 \& K2) lacking noticeable cyanobacterial growth. The summer average species richness was not significantly different from that of either autumn or spring. The nMDS analysis performed for each cave revealed a different seasonal pattern of cyanobacterial community. In particular:

In 'Kastria' the seven sampling sites were grouped in three clusters (Fig. 4): (i) the entrance zone consisting of sites $1,2,3$, (ii) the transition zone consisting of sampling site 5 , and (iii) the dim light zone consisting of sampling sites 6,7 . The samples of site 4 were more dispersed indicating seasonal variation, still the nMDS 3D configuration (not shown here) revealed the site's distinction from the rest. The entrance community was the richest (51 taxa) followed by the transition and the dim light zone (33 and 18 taxa respectively).

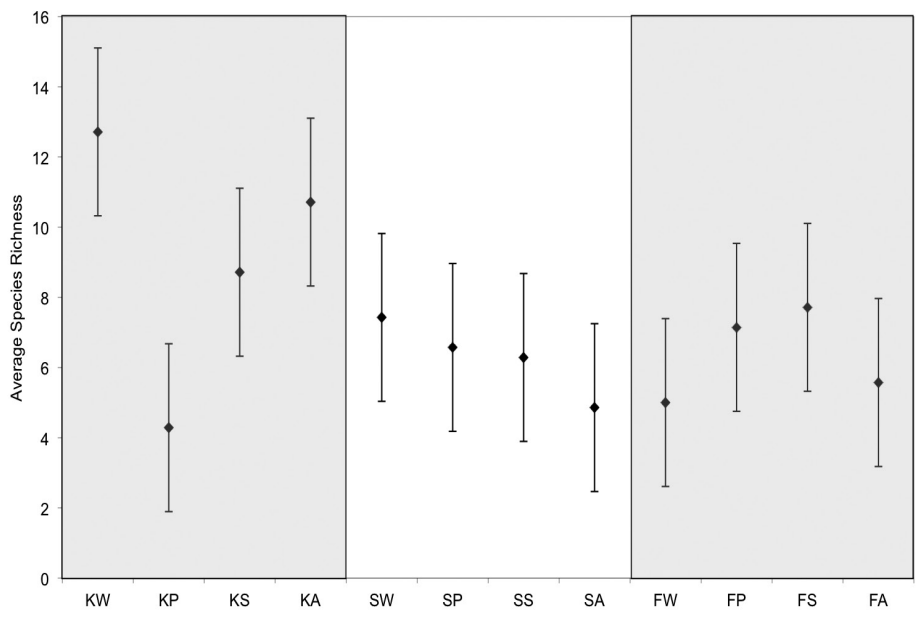

Fig. 3. ANOVA of the average species richness per season (error bars $=95 \%$ LSD) showing the differentiation among caves ( $K=$ 'Kastria', $\mathrm{S}=$ 'Selinitsa', $\mathrm{F}=$ = 'Francthi', $\mathrm{W}=$ Winter, $\mathrm{P}=$ Spring, $\mathrm{S}=$ Summer, $A=$ Autumn).

In 'Francthi' the seven sampling sites were grouped in two major clusters (Fig. 5): (i) the first one consisting of sampling sites 1-5 with seasonal subgrouping, and (ii) the second one with sampling sites 6 (stalagmite) and 7 (stalactite). Analysis of species richness revealed 52 and 32 taxa in the above clusters, respectively.

In 'Selinitsa' the seven sampling sites were grouped in three clusters (Fig. 6): (i) the entrance zone, mostly affected by the sea spray, consisting of sampling sites 1,3 , (ii) the transition zone, in terms of PAR and influence of the salt spray, consisting of sampling site 2 , and (iii) the dim light zone consisting of sampling sites $4,5,6,7$. The species richness was higher at the entrance zone (48 taxa); the transition and the dim light zones followed with 11 and 35 taxa, respectively.

Table 2. Results of SIMPER analysis among pairs of caves based on the cumulative seasonal species composition, showing the percentage $(\%)$ average dissimilarity $(A D)$ and the responsible distinctive species.

\begin{tabular}{|c|c|c|}
\hline $86.25 \%$ & $86.35 \%$ & $88.98 \%$ \\
\hline $\begin{array}{l}\text { Kastria } \\
\text { Scytonema julianum(Kützing) } \\
\text { Meneghini } \\
\text { Iphinoe spelaeobios Lamprinou \& } \\
\text { Pantazidou } \\
\text { Pseudophormidium spelaeoides (Čado) } \\
\text { Anagnostidis } \\
\text { Lyngbya palikiana Claus } \\
\text { Francthi } \\
\text { Chroococcidiopsis kashaii Friedmann } \\
\text { Pseudophormidiumsp. (Forti) } \\
\text { Anagnostidis \& Komárek } \\
\text { Leptolyngbya gracillima (Zopf } \\
\text { ex Hansgirg) Anagnostidis \& } \\
\text { Komárek }\end{array}$ & $\begin{array}{l}\text { Francthi } \\
\text { Pseudophormidium sp. (Forti) } \\
\text { Anagnostidis \& Komárek } \\
\text { Cyanosarcina (sp.3) Kováčik } \\
\text { Nostoc (sp.3) Vaucher ex Bornet \& Fla- } \\
\text { hault } \\
\text { Asterocapsa aerophytica Lederer } \\
\text { Chroococcus cf. lithophilus Ercegović } \\
\text { Selinitsa } \\
\text { Leptolyngbya tenuis (Gomont) } \\
\text { Anagnostidis \& Komárek } \\
\text { Cyanosarcina (sp.1) Kováčik } \\
\text { Nostoc macroscporum Meneghini ex } \\
\text { Bornet \& Flahault }\end{array}$ & $\begin{array}{l}\text { Kastria } \\
\text { Scytonema julianum (Kützing) Meneghini } \\
\text { Iphinoe spelaeobios Lamprinou \& } \\
\text { Pantazidou } \\
\text { Pseudophormidium spelaeoides (Čado) } \\
\text { Anagnostidis } \\
\text { Leptolyngbya gracillima (Zopf ex } \\
\text { Hansgirg) Anagnostidis \& Komárek } \\
\text { Lyngbya palikiana Claus } \\
\text { Selinitsa } \\
\text { Chroococcidiopsis kashaii Friedmann } \\
\text { Nostoc commune Vaucher ex Bornet \& } \\
\text { Flahault }\end{array}$ \\
\hline
\end{tabular}


Table 3. Average seasonal values and standard deviation of Photosyntheticaly Active Radiation (PAR), Temperature ( $T$ ) and Relative Humidity $(\mathrm{RH})$ measured in the three caves ( $\mathrm{K}=$ 'Kastria', $\mathrm{S}=$ 'Selinitsa', $\mathrm{F}=$ 'Francthi', $\mathrm{W}=$ Winter, $\mathrm{P}=\mathrm{Spring}, \mathrm{S}=\mathrm{Summer}, \mathrm{A}=\mathrm{Autumn}$ ).

\begin{tabular}{|c|c|c|c|c|c|c|}
\hline & \multicolumn{2}{|c|}{ PAR } & \multicolumn{2}{c|}{${ }^{\mathrm{T}}$} & \multicolumn{2}{c|}{$\begin{array}{c}\text { RH } \\
\%\end{array}$} \\
\hline & average & $\mathrm{sd}$ & average & sd & average & sd \\
\hline FA & 2.58 & 2.70 & 19.50 & 2.06 & 89.00 & 5.23 \\
\hline FP & 0.71 & 0.56 & 12.53 & 0.53 & 53.66 & 2.46 \\
\hline FS & 1.32 & 0.86 & 25.10 & 0.81 & 62.18 & 4.86 \\
\hline FW & 7.75 & 12.83 & 15.92 & 1.15 & 59.97 & 4.96 \\
\hline KA & 0.40 & 0.60 & 12.01 & 0.35 & 90.17 & 4.59 \\
\hline KP & 4.24 & 7.85 & 12.37 & 1.37 & 92.04 & 5.59 \\
\hline KS & 4.70 & 8.15 & 16.21 & 3.56 & 81.63 & 13.78 \\
\hline KW & 6.20 & 15.07 & 6.60 & 0.69 & 92.35 & 4.42 \\
\hline SA & 12.08 & 16.89 & 20.08 & 0.43 & 75.90 & 2.76 \\
\hline SP & 4.46 & 7.28 & 16.73 & 0.40 & 68.11 & 10.95 \\
\hline SS & 10.10 & 12.25 & 20.66 & 4.03 & 64.26 & 6.53 \\
\hline SW & 2.77 & 4.15 & 16.05 & 0.48 & 86.31 & 2.20 \\
\hline
\end{tabular}

\section{DISCUSSION}

Although a photosynthetic microflora consisting of various algal groups was found in sites of the three caves with adequate light, Cyanobacteria were found to prevail especially in the low light zone (see also Albertano, 1999; Hernández-Mariné et al., 2001; Lamprinou et al., 2009). A general pattern of cyanobacterial distribution in relation to the environmental parameters examined (PAR, T, RH) cannot be determined in the caves investigated herein. The morphology of the cave, the water availability, the type and the coherence of the substratum apart from the abiotic parameters might thus explain the variations in species composition (see also Roldán et al., 2004).

However, in the typical cave 'Kastria' where light shows a clear gradient from the entrance inwards, the cyanobacterial community is organized into mosaics following the expected 'typical' (entrance, transition and dim light zone) pattern of cyanobacterial distribution. The entrance community zone shows biofilms with the highest number of species mostly of the order Chroococcales (see also Roldán \& Hernández-Mariné, 2009). Mucilaginous, 'temporary' biofilms protected against dessication and direct light were prevailing at the entrance zone, with the following characteristic taxa: Aphanocapsa spp., Chroococcus spp., Eucapsis minor, Leptolyngbya gracillima, L. perelegans and Pseudophormidium spelaeoides. On the contrary, the dim light community zone is characterized by a lower number of species with Oscillatoriales prevailing over Chroococcales (see also Vinogradova et al., 1998; Roldán \& Hernández-Mariné, 2009). Biofilms there become thinner and less mucilaginous, and taxa with calcified filaments able to survive at dim light, such as Scytonema julianum and Iphinoe spelaeobios, are prevailing. Presence of species with carbonate precipitates on the polysaccharide sheaths has been previously reported from dim light zones of caves (Hernández-Mariné et al., 2001; Roldán et al., 2004). It is noted that Scytonema julianum together with the species Leptolyngbya palikiana, L. gracillima, Pseudophormidium spelaeoides, were almost always present from the entrance to the deeper part of cave

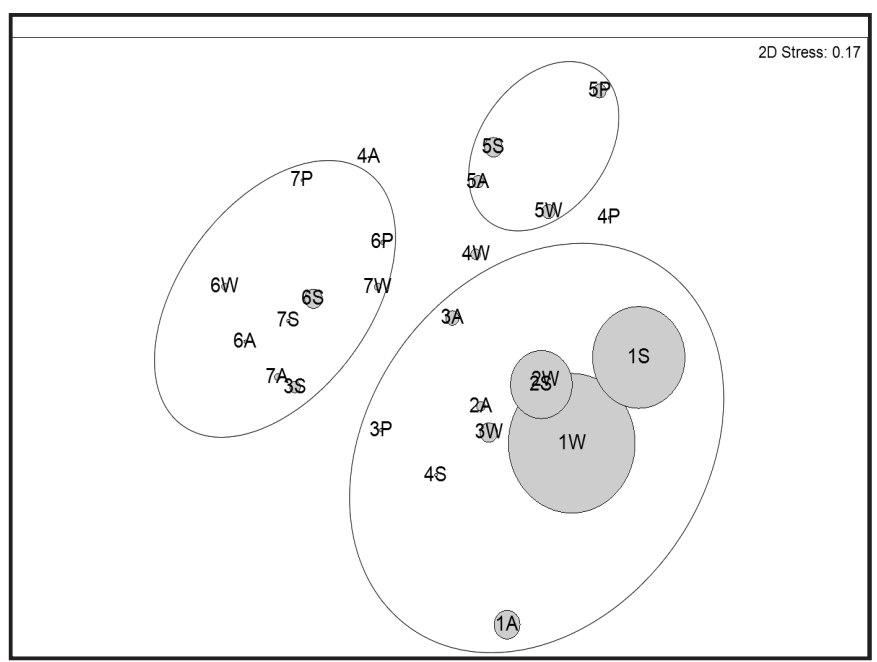

Fig. 4. In cave 'Kastria', nMDS analysis of the cumulative seasonal samples per sampling site with superimposed the average value of PAR. Grouping of sampling sites (1-7) in three clusters is shown. (W = Winter, $\mathrm{P}=$ Spring, $\mathrm{S}=$ Summer, $\mathrm{A}=$ Autumn).

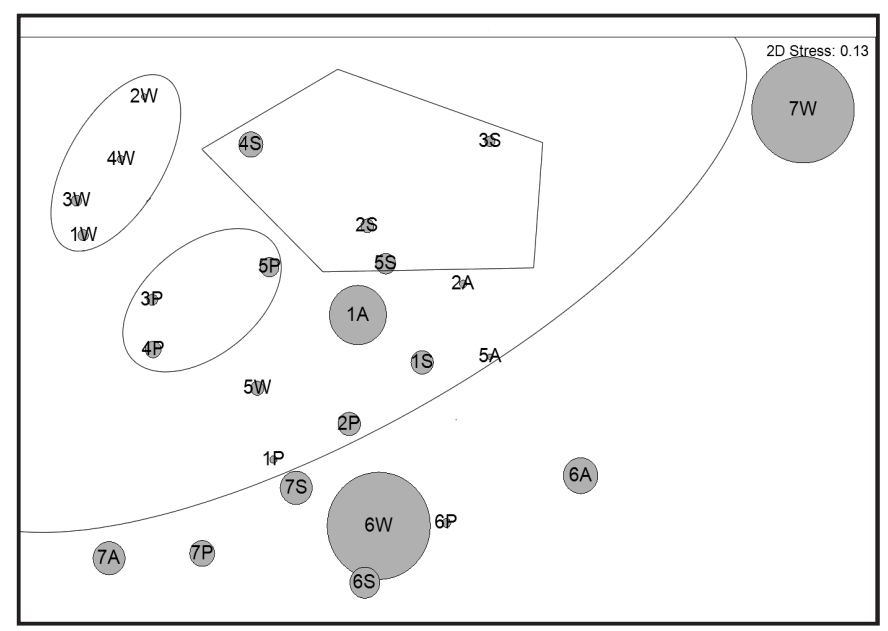

Fig. 5. In cave 'Francthi', nMDS analysis of the cumulative seasonal samples per sampling site with superimposed the average value of PAR. Grouping of sampling sites (1-7) in two clusters is shown. (W $=$ Winter, $\mathrm{P}=$ Spring, $\mathrm{S}=$ Summer, $\mathrm{A}=$ Autumn). 


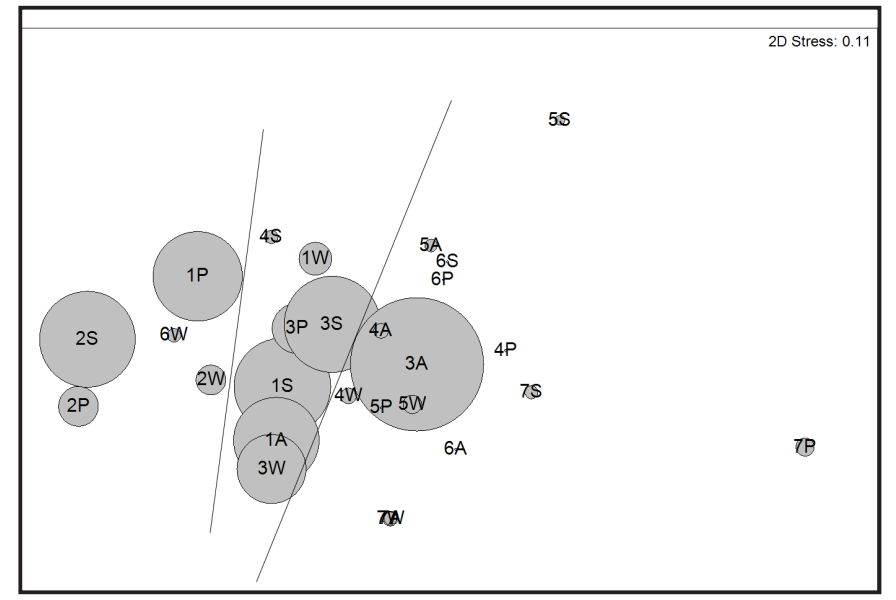

Fig. 6. In cave'Selinitsa', nMDS analysis of the cumulative seasonal samples per sampling site with superimposed the average value of PAR. Grouping of sampling sites (1-7) in three clusters is shown. ( $W=$ Winter, $P=$ Spring, $S=$ Summer, $A=$ Autumn).

'Kastria'. According to Hoffmann (2002) Scytonema julianum can be characterized as a troglophile species, and according to previous reports from caves (Couté \& Bury, 1988; Ariño et al., 1997; Roldán \& Hernández-Mariné, 2009) this species seems to bear strong environmental fluctuations.

The presence of filamentous heterocytous cyanobacterial species with ability to fix atmospheric $\mathrm{N}_{2}$ and produce exopolymeric polysaccharide substances (EPSs), like those of the genus Nostoc observed in most sites of 'Selinitsa' - a'typical' cave but affected by the sea spray-, might be a clear advantage for incave environment. It is known that nitrogen is a nutrient limiting algal growth; as a result the capacity of the heterocytous cyanobacteria to fix nitrogen plays an important role especially in these poor environments (Asencio \& Aboal, 2011). The same is true for Chroococcidiopsis kashaii, a species always present in this cave in biofilms with abundant EPS, since these substances are crucial for increasing dessication tolerance (see also Zammitt et al., 2011).

Predominance of Oscillatoriales over Chroococcales, like that observed in the dim light zone of 'Kastria', was also observed in the open air cave 'Francthi', especially in sites of speleothems (stalagmites, stalactites) exposed in light, but their presence there is attributed to the chasmoendolithic mode of life.

It is worth noticing that new genera and species have already been established from the three investigated Greek caves, i.e. Iphinoe spelaeobios Lamprinou \& Pantazidou (Lamprinou et al., 2011), Iphinoe cf. spelaeobios Lamprinou \& Pantazidou (Lamprinou et al., 2012b), Toxopsis calypsus Lamprinou \& Pantazidou (Lamprinou et al., 2012a), Phormidium melanochroun Lamprinou \& Pantazidou (Lamprinou et al., 2012c), enhancing the view that hypogean environments in general may favor speciation or physiological adaptation (Lamprinou et al., 2009; Zammitt et al., 2011). Therefore, the species distribution in relation to cave morphology, lithic substrate, and microclimatic conditions still remain a challenge for further research.

\section{REFERENCES}

Abdelahad N., 1989 - On four Myxosarcina-like species (Cyanophyta) living in the Inferniglio cave (Italy). Algological Studies, 54: 3-13.

Albertano C., 1999 - Structural interactions among epilithic cyanobacteria and heterotrophic microorganisms in Roman hypogea. Microbial Ecology, 38: $244-252$.

http:/ /dx.doi.org/10.1007/s002489900174

Anagnostidis K., Economou-Amilli A. \& Pantazidou A., 1982 - On the microflora of cave Perama, Ioannina. Bulletin de la Société Spéléologie de Grèce, 18: 458-530.

Ariño X., Hernández-Mariné M. \& Saiz-Jiménez C., 1997 - Colonization of Roman tombs by calcifying cyanobacteria. Phycologia, 36: 366-373.

http://dx.doi.org/10.2216/i0031-8884-36-5-366.1

Asencio A. \& Aboal M., 1996 - Cyanophytes from Andragullaabrigo (Murcia, SE Spain) and their environental conditions. Algological Studies, 83: 55-72.

Asencio A. \& Aboal M., 2000a - A contribution to knowledge of chasmoendolithic algae in cave-like environments. Algological Studies, 98: 133-151.

Asencio A \& Aboal M., 2000b - Algae from Seretta cave (Murcia, SE Spain) and their environmental conditions. Algological Studies, 69: 59-78.

Asencio A. \& Aboal M., 2011 - In situ acetylene reduction activity of Scytonema julianum in Vapor cave (Spain). International Journal of Speleology, 40: $17-21$. http://dx.doi.org/10.5038/1827-806X.40.1.3

Borzi A., 1917 - Studi sulle Mixoficee. Nuovo Giornale Botanico Italiano, 24: 100-112.

Bourelly P. \& Dupuy P., 1973 - Quelques stations françaises de Geitleria calcarea, Cyanophycée cavernicole. Schweizerische Zeitschrift für Hydrobiology, Fishereiwissenschaft, Abwasserreinigung, 35: 136-140.

Claus G., 1964 - Algae and their mode of life in the Baradla Cave at Aggtelek II. International Journal of Speleology, 1: 13-17.

Couté A. \& Bury E., 1988 - Ultrastructure d'une cyanophycée aérienne calcifiée cavernicole: Scytonema julianum (Frank) Richter (Hormogonophycidae, Nostocales, Scytonemataceae). Hydrobiologia, 160: 219-239. http://dx.doi.org/10.1007/BF00007137

Culver D.C., Christman M.C., Sket B. \& Trontelj P., 2004 - Sampling adequacy in an extreme environment: Species richness patterns in Slovenian caves. Biodiversity and Conservation, 13: 1209-1229. http://dx.doi.org/10.1023/B:BIOC.0000018153.49280.89

Dobat K., 1977 - Zur Ökogenese und Ökologie der Lampenflora deutscher Schauhohlen. In: Frey, W. (ed) Beitrage zur Biologie der niederen Pflanzen. Gustav Fischer Verlag, Stuttgart: 177-215.

Friedmann I., 1964 - Progress in the biological exploration of caves and subterranean waters in Israel. International Journal of Speleology, 1: 29-33.

Hajdu I., 1966 - Algological studies in the cave of Matyas Mount, Budapest, Hungary. International Journal of Speleology, 2: 137-149. 
Hernández-Mariné M., Roldán M., Clavero E., Canals A. \& Ariño X., 2001- Phototrophic biofilm morphology in dim light. The case of the Puigmolto sinkhole. Nova Hedwigia, 123: 237-253.

Hoffmann L., 1989 - Algae of terrestrial habitats. Botanical Review, 55: 77-105. http:/ /dx.doi.org/10.1007/BF02858529

Hoffmann L., 2002 - Caves and other low-light environments: Aerophytic photoautotrophic microorganisms. In: Bitton G. (Ed)., Encyclopedia of Environmental Microbiology. New York: John Wiley \& Sons: 835-843.

Lamprinou V., Pantazidou A., Papadogiannaki G., Radea C. \& Economou-Amili A., 2009 Cyanobacteria and associated invertebrates in Leontari cave. Fottea, 9: 155-164.

Lamprinou V., Hernandez-Marine M., Canals T., Kormas K., Economou-Amilli A. \& Pantazidou A., 2011 - Morphology and molecular evaluation of Iphinoe spelaeobios gen. nov., sp. nov. and Loriellopsis cavernicola gen. nov., sp. nov., two stigonematalean cyanobacteria from Greek and Spanish caves. International Journal of Systematic and Evolutionary Microbiology, 61: 2907-2915. http://dx.doi.org/10.1099/ijs.0.029223-0

Lamprinou V., Skaraki K., Kotoulas G., EconomouAmilli A. \& Pantazidou A., 2012a - Toxopsis calypsus gen. nov., sp. nov. (Cyanobacteria, Nostocales) from cave 'Francthi', Peloponnese, Greece - Morphological and molecular evaluation. International Journal of Systematic and Evolutionary Microbiology, published ahead of print January 13, 2012. http://dx.doi.org/10.1099/ijs.0.038679-0

Lamprinou V., Hernández-Mariné M., Pachiadaki M.G., Kormas K.A., Economou-Amilli A. \& Pantazidou A., 2012b - New findings on the truebranched monotypic genus Iphinoe (Cyanobacteria) from geographically isolated caves (Greece). Fottea (accepted).

Lamprinou V., Skaraki K., Kotoulas G., Anagnostidis K., Economou-Amilli A. \& Pantazidou A., 2012c - A new species of Phormidium (Cyanobacteria, Oscillatoriales) from Greek Caves. - Morphological and Molecular Evaluation. Fundamental and Applied Limnology (submitted).

Leclerc J. C., Couté A. \& Dupuy P., 1983 - Le climat annuel de deux grottes et d'une weglise du Poitou. Cryptogamie Algologie, 4: 1-19.
Martinez A. \& Asencio A.D., 2010 - Distribution of cyanobacteria at the Gelada cave (Spain) by physical parameters. Journal of Cave and Karst Studies, 72: 11-20.

http://dx.doi.org/10.4311/jcks20091sc0082

Mulek J. \& Kosi G., 2008 - Algae in the aerophytic habitat of Racise ponikve cave (Slovenia). Natura Sloveniae, 10: 39-49.

Roldán M., Clavero E., Canals T.A., Ariño X. \& Hernández-Mariné M., 2004 -Distribution of phototrophic biofilms in cavities (Garraf, Spain). Nova Hedwigia, 78: 329-351.

http://dx.doi.org/10.1127/0029-5035/2004/0078-0329

Roldán M. \& Hernández-Mariné M., 2009 - Exploring the secrets of the three-dimensional architecture of phototrophic biofilms in caves. International Journal of Speleology, 38: 41-53.

Sant'Anna C., Branco L. \& Silva S., 1991 - A new species of Gloeothece (Cyanophyceae, Microcystaceae) from São Paulo State, Brazil. Algological Studies, 92: $1-5$.

Seckbach J, Chapman D., Garbary D.J., Oren A. \& Reisser W. 2007 - Algae and Cyanobacteria under environmental extremes. In: Seckbach (ed) Algae and Cyanobacteria in Extreme Environments. Israel: Springer: 783-786.

Şerbānescu V. \& Decu M., 1962 - To the knowledge of cavernicolous algae of Oltenia. Revue de Biologie. Revue de Biologie, 7: 201-214.

Skuja H., 1970 - Alghe cavernicolenelle zone illuminate delle grotte di Castellana (Murge di Bari). La Grotte d' Italia, 4: 193-202.

Stanier R.Y., Kunisawa R., Mandel R. \& CohenBazire G., 1971 - Purification and properties of unicellular blue green algae (Order Chroococcales). Bacteriological Reviews, 35: 171-205.

Vinogradova O.N., Kovalenko O.V., Wasser S.P., Nevo E. \& Weinstein-Evron M., 1998 - Species diversity gradient to darkness stress in blue-green algael cyanobacteria: a microscale test in a prehistoric cave, Mount Carmel, Israel. Israel Journal of Plant Sciences, 46: 229-238.

Zammitt G., Billi D., Shubert E., Kaštovský J. \& Albertano P., 2011 - The biodiversity of subaerophytic phototrophic biofilms from Maltese hypogea. Fottea, 11: 187-201. 